\title{
Seasonal variations in concentration and microbial uptake of methylamines in estuarine waters
}

\author{
Xiao-Hua Yang, Mary I. Scranton, Cindy Lee \\ Marine Sciences Research Center, State University of New York, Stony Brook, New York 11794-5000, USA
}

\begin{abstract}
Concentrations and heterotrophic uptake rates of monomethylamine, dimethylamine, and trimethylamine in estuarine seawater were measured. There was a strong seasonal variation in the abundance and biological uptake of these compounds. Both concentrations and heterotrophic uptake rates of the 3 methylamines (MA) are higher in summer than in winter. Turnover times of the MA are shorter in summer (several hours) than in winter (thousands of hours). DMA is the most abundant (15 to $180 \mathrm{nM}$ ) and has the fastest uptake rate $\left(0.1\right.$ to $12 \mathrm{nM} \mathrm{h} \mathrm{h}^{-1}$ ), while MMA and TMA have lower concentrations ( 5 to $60 \mathrm{nM}$ ) and slower uptake rates $\left(0.01\right.$ to $\left.2.4 \mathrm{nM} \mathrm{h}^{-1}\right)$. Uptake rates of MA were not inhibited by addition of $1 \mu \mathrm{M}$ ammonium. Changes in seasonal distributions of MA and their uptake rates suggest that biological production of $\mathrm{MA}$ is greatest in the summer months and is lower in the winter.
\end{abstract}

KEY WORDS: Methylamines Microbial uptake Seasonal varnations Estuary

\section{INTRODUCTION}

Monomethylamine (MMA), dimethylamine (DMA), and trimethylamine (TMA) are low molecular weight organic nitrogen compounds found in both terrestrial and marine environments (Smith 1971, Yancey et al. 1982, King 1988). In seawater, methylamines (MA) are products of degradation, excretion and metabolism by marine animals and bacteria (Hebard et al. 1982, King 1984, Sørensen \& Glob 1987). Methylamines can be taken up by heterotrophic bacteria (Budd \& Spencer 1968, King et al. 1983, Lee 1992), facultative methylotrophs (King 1984, Gottschalk 1986), and cyanobacteria (Boussiba et al. 1984, Kerby et al. 1986, Gunnersen et al. 1988). There is some evidence that MA can be taken up by marine phytoplankton, including diatoms (Wheeler 1980, Wheeler \& Hellebust 1981, Wright \& Syrett 1983), microflagellates (Koike et al. 1983), dinoflagellates and coccolithophorids (Balch 1985, 1986). Reports of uptake by macroalgae (Wheeler 1978, MacFarlane \& Smith 1982) and by some symbionts with zooplankton (D'Elia \& Cook 1988) also exist. In spite of the qualitative knowledge that MA are commonly produced and used by many marine organisms, concentrations and production and consumption rates in seawater are not well known due to the difficulty in measuring the low concentrations of these compounds usually found in the marine environment. Most previous uptake studies measured only turnover times in seawater rather than uptake rates since the ambient concentrations of $\mathrm{MA}$ were not known.

Although a number of studies have reported measuring concentrations of methylamines in pore waters and sediment (King et al. 1983, Lee \& Olson 1984, Sørensen \& Glob 1987, Wang \& Lee 1990), very few studies have determined the concentration of any MA dissolved in seawater (Mopper \& Zika 1987, Sørensen \& Glob 1987, Van Neste et al. 1987). Recently we developed a diffusion method that uses Teflon membranes and is capable of measuring various amines in seawater at concentration ranges from $\mathrm{nM}$ to $\mu \mathrm{M}$ (Yang et al. 1993). In the work we report here, we use this technique to measure seasonal and diel variations in the concentration of MA and investigate the role of bacterial uptake in controlling these concentrations. 


\section{MATERIALS AND METHODS}

Description of study area. Flax Pond, New York, USA, is a salt marsh located on the north shore of Long Island and is connected to Long Island Sound by a single manmade channel (Woodwell \& Pecan 1973). There is very little freshwater drainage into the marsh. Except for the tidal creeks and flats, the marsh surface is primarily covered with marsh plants such as Spartina altemiflora ( $46 \%$ of the marsh surface), S. patens and Distichlis spicata $(7 \%)$ and Salicornia spp. The salinity in Flax Pond usually ranges between 26 and $28 \%$.

Seasonal and daily variations. Concentrations and heterotrophic uptake rates of MA were measured monthly from April 1990 to April 1991. On 2 August 1990 , the variation with time of both concentration and heterotrophic uptake rate of MA were measured. Samples were taken during daylight at 08:00, 12:00, 16:00 and 20:00 h. Water temperatures were 22.5, 25.5, 26 and $25.5^{\circ} \mathrm{C}$ respectively at these times. High tides occurred at 08:00 and 20:20 h. Samples to investigate temperature effects on uptake rate were taken in February and March 1991 and were incubated at 7 and $24^{\circ} \mathrm{C}$

Heterotrophic uptake. In order to determine heterotrophic uptake rates of MA in seawater, unfiltered seawater samples were incubated with ${ }^{14} \mathrm{C}$-methylamines at in situ temperatures. Both incorporation into cellular constituents and respiration to $\mathrm{CO}_{2}$ were measured in all uptake experiments. All seawater samples were collected at least $60 \mathrm{~cm}$ above the sediment in acid-washed plastic bottles. Seawater was inoculated with $45 \mathrm{nCi}$ of ${ }^{14} \mathrm{C}$-labeled MA in $100 \mu$ distilled water and incubated. Specific activities of the labels were $48 \mathrm{mCi} \mathrm{mmol}^{-1} \mathrm{MMA} 54 \mathrm{mCi} \mathrm{mmol}^{-1} \mathrm{DMA}$, and $3 \mathrm{mCi} \mathrm{mmol}{ }^{-1}$ TMA. The spikes resulted in an increase of about 20 nM MMA and DMA and 300 nM TMA. An attempt was made to minimize the amount of label added in order to perturb the system as little as possible. However, achieving true tracer concentrations (less than $10 \%$ of natural concentrations) was not possible using ${ }^{14} \mathrm{C}$ since specific activities of these small amines are very low. ${ }^{14} \mathrm{C}$-labeled compounds were used instead of higher specific activity tritiated compounds because of the ease of measurement of ${ }^{14} \mathrm{CO}_{2}$ relative to the distillation method (Azam \& Hodson 1981) required for ${ }^{3} \mathrm{H}_{2} \mathrm{O}$. Respiration was measured in a large number of samples almost simultaneously so ease of measurement was critical. The percent of label consumed in these experiments was always less than $15 \%$. This method should give reasonable estimates of rate constants where substrate saturation has not been reached (Wright \& Hobbie 1966, Billen et al. 1980) and multiphasic kinetics do not occur (Azam \& Hodson 1981).
The microbial decomposition rate is assumed to be the same as the microbial uptake rate, which was measured as the sum of respiration and incorporation of label over time. Assuming first-order kinetics, the rate constant of decomposition of substrate $S$ can be estimated from a plot of $-\ln \left[S / S_{0}\right]$ versus incubation time. $S_{0}$ is the substrate concentration at time zero. If added label behaves similarly to the natural substrate, then $S$ at time $t$ equals $S_{0}-f S_{0}$ where $f$ is the fraction of label taken up at time $t$, and thus $S / S_{0}$ equals $(1-f)$. The turnover time is the reciprocal of the first-order rate constant, $k$. The decomposition rate, $v$, can be determined as the product of the rate constant and $\left[S_{n}\right]$, the natural substrate concentration, or $v=k\left[S_{n}\right]$. In a typical example for the 3 amines at a single sampling time, Fig. 1 shows the linearity of results obtained using this technique.

Respiration was measured as the production of ${ }^{14} \mathrm{CO}_{2}$ from the labeled substrate. Activity in the $\mathrm{CO}_{2}$ produced was measured on duplicate samples by passive distillation of the $\mathrm{CO}_{2}$ onto protosol-soaked wicks. The $\mathrm{CO}_{2}$ was liberated from solution by acidifying $5 \mathrm{ml}$ of seawater with $18 \mathrm{~N} \mathrm{H}_{2} \mathrm{SO}_{4}$ through a serum stopper and shaking for $1 \mathrm{~h}$. Both the wick and the remaining acidified seawater were counted to provide a check on label recovered in the distillation. Recovery was always greater than $85 \%$. Incorporation of label was measured by filtering duplicate subsamples onto $0.22 \mu \mathrm{m}$ Millipore filters to measure uptake into the particulate fraction. Aquasol or Optifluor was used as the scintillation fluor, and recounts showed the absence of chemiluminescence. Counting was to $1 \%$ error and quench corrections were made by the channels ratio method

Ambient methylamine concentrations. Water samples were filtered through combusted $\left(500^{\circ} \mathrm{C}\right.$ for $5 \mathrm{~h}$ ) Whatman GF/F and then $0.22 \mu \mathrm{m}$ Millipore filters: $2 \mathrm{ml}$ of $6 \mathrm{~N} \mathrm{HCl}$ were added immediately after filtration to each liter of sample. Acidified samples were stored in the refrigerator for up to 2 wk before analysis. Concentrations of MA were determined by the circulation diffusion method described previously (Yang et al 1993). Duplicate analyses varied within \pm 10 to $15 \%$.

Kinetic parameters. We can calculate $V_{\text {max }}$ the maximum uptake achievable by increasing substrate concentration, and $K_{t}$, a transport constant that is a measure of the affinity of the uptake system for a substrate, by assuming kinetic homogeneity for the microbial population and a Michaelis-Menten enzyme kinetics model (Wright \& Hobbie 1966, Azam \& Hodson 1981). Incubations were conducted by spiking with appropriate concentrations of unlabeled MA into unfiltered seawater in March 1991 and July 1992 using 10 different concentrations in the spring $(80 \mathrm{nM}$ to $2 \mu \mathrm{M})$ and 4 in the summer $(0.5$ to $500 \mu \mathrm{M})$. The 
uptake rates were calculated in the same manner as described above, but for each added concentration From a Lineweaver-Burk plot of $1 / v$ as a function of $1 / S, K_{t}$ was read as the $x$-intercept and $1 / V_{\max }$ as the $y$-intercept (Fig. 2).

Competition experiment. Bacterial competition experiments were conducted on 10 September 1990 and have been described by Jorgensen et al. (1993) In these experiments, plastic buckets were filled with $10 \mathrm{l}$ of $0.22 \mu \mathrm{m}$ filtered seawater, and $0.5 \mathrm{l}$ of bacterial inoculum (1 $\mu \mathrm{m}$ Nuclepore filtered seawater) was added. The effects on bacterial growth parameters of nutrient additions were tested by adding $1 \mu \mathrm{M} \mathrm{NH_{4 }}$ (enrichment B), $0.6 \mu \mathrm{M}$ each of MMA, DMA, and TMA (enrichment $C$ ), and the previous mixture of MA plus $1 \mu \mathrm{M} \mathrm{NH}_{4}$ (enrichment D). The fourth bucket was the control (A). The buckets were incubated at room temperature in the dark for $14 \mathrm{~h}$. Then, subsamples were taken from each bucket for measurement of $\mathrm{MA}$ concentrations and heterotrophic uptake rate constants.

Tank experiment. Flax Pond seawater was isolated in a white $167 \mathrm{l}$ plastic tank and placed in the marsh just below the level of high tide. Concentrations and heterotrophic uptake rates of MA were measured 4 times during a diel cycle starting at 14:00 h (20 to 21 May 1992) and compared with the ambient seawater. Because the tank was grounded during low tide, it was exposed to the sun and warmed during this time Temperatures in the tank were thus $20,19,19$, and $23^{\circ} \mathrm{C}$ in the tank and $20,16,18$, and $21^{\circ} \mathrm{C}$ in the ambient seawater at the sampling times.

\section{RESULTS}

\section{Seasonal and daily variations}

DMA was the most abundant MA throughout the year (Fig. 3A) and varied significantly, while MMA and TMA concentrations were lower. Concentrations of DMA ranged from a low of $25 \mathrm{nM}$ in January to highs of $180 \mathrm{nM}$ in May and September. Concentrations of MMA and TMA were lower, ranging from between 5 and $10 \mathrm{nM}$ in December and January to between 40 and $50 \mathrm{nM}$ during May through September. Turnover times of all 3 MA were 100 to 200 times shorter in summer than in winter (Fig. 3B) and ranged from several hours to $100 \mathrm{~d}$. The heterotrophic uptake rate of DMA was 5 to 10 times higher than that of MMA or TMA. Uptake rates of all 3 MA were higher in the summer ( 1 to $4 \mathrm{nM} \mathrm{h}^{-1}$ for MMA and TMA, 10 to $20 \mathrm{nM} \mathrm{h}^{-1}$ for DMA) than in the winter (0.002 to $0.004 \mathrm{nM} \mathrm{h}^{-1}$ for MMA and TMA, $0.011 \mathrm{nM}^{-1}$ for DMA) (Fig. 3C).

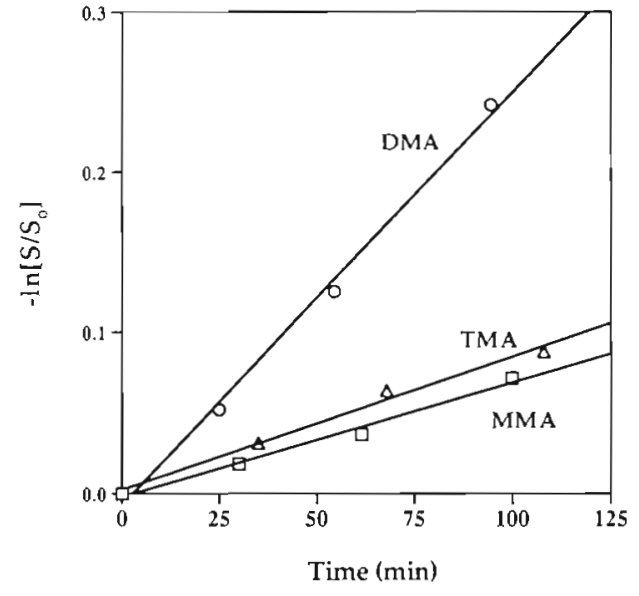

Fig. 1 An example of a kinetic plot used to calculate uptake rate constants for MMA $\left(\mathrm{r}^{2}=0.99\right)$, DMA $\left(\mathrm{r}^{2}=0.99\right)$, and TMA $\left(r^{2}=0.99\right)$
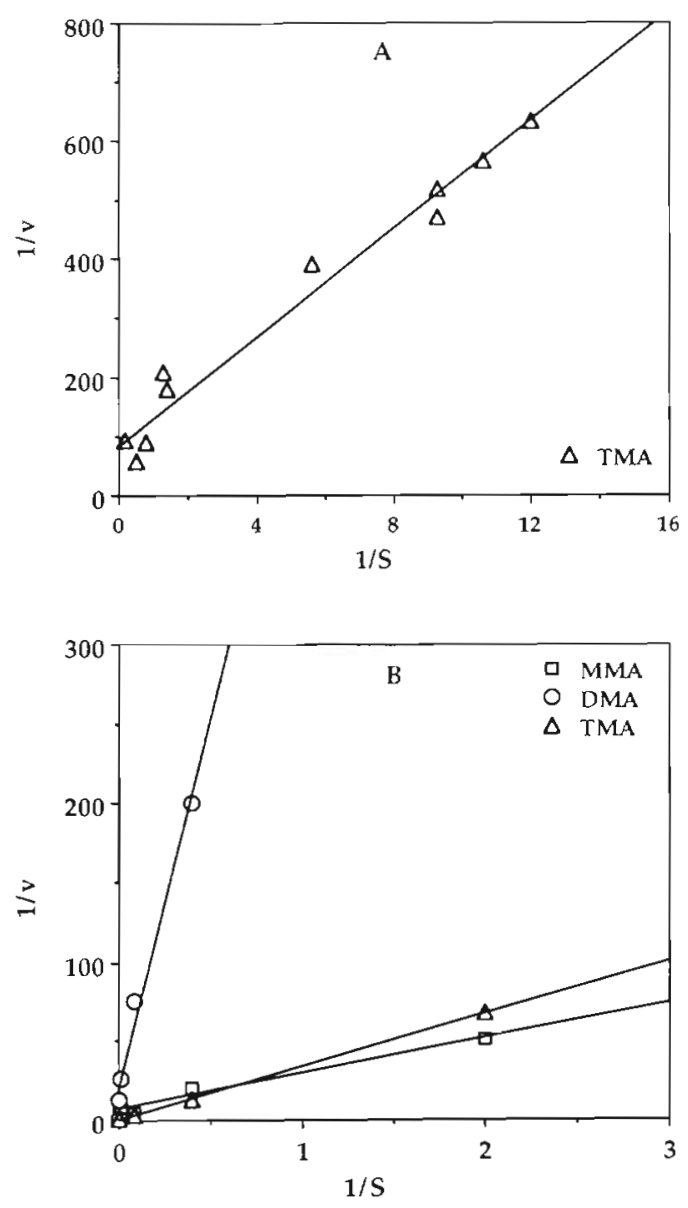

Fig. 2. An example of the Lineweaver-Burk plot used to calculate $K_{t}$ and $V_{\max }:(A)$ for TMA $\left(r^{2}=0.97\right)$ during March and (B) for MMA $\left(r^{2}=0.97\right)$, DMA $\left(r^{2}=0.97\right)$, and TMA $\left(r^{2}=0.99\right)$ during July. Units of $S$ are $\mu \mathrm{M}$; units of $v$ are $\mathrm{nmol} \mathrm{h}^{-1}$ in March and $\mu \mathrm{mol} \mathrm{h}^{-1}$ in July 

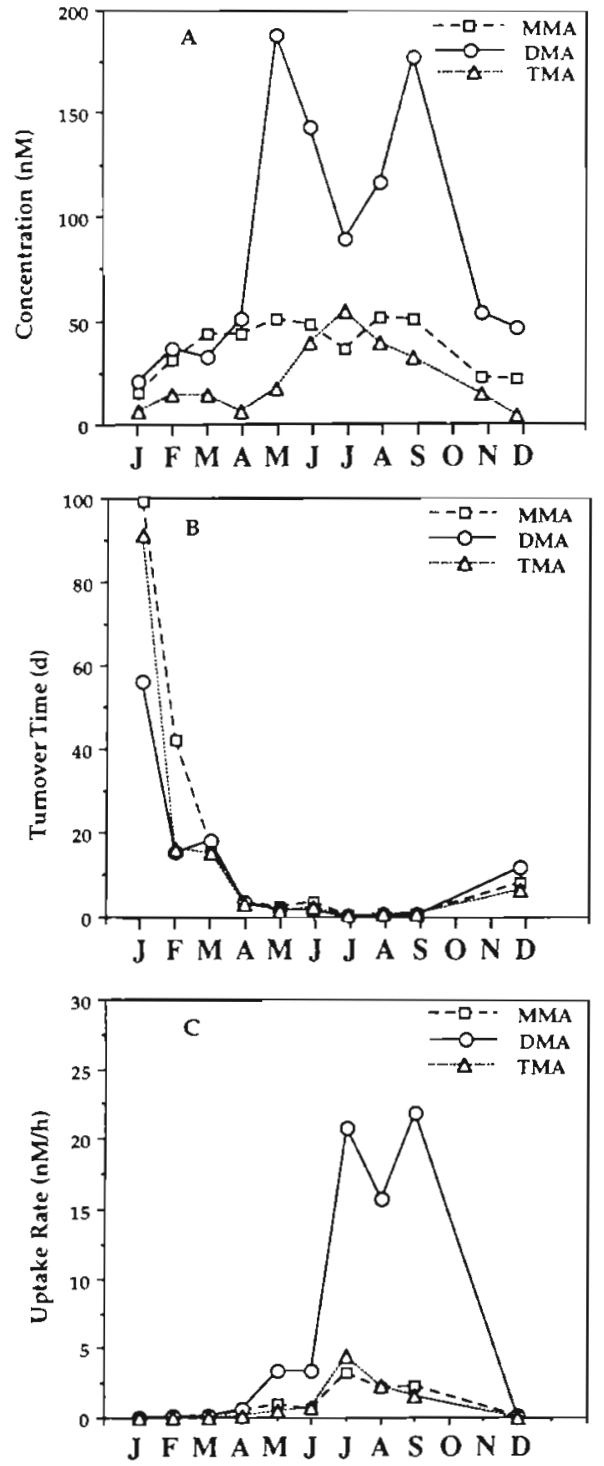

Fig. 3. Seasonal variations in (A) concentrations, (B) turnover times, and $(C)$ heterotrophic uptake rates of MMA, DMA, and TMA in Flax Pond seawater

On 2 August 1990, concentrations of MMA and DMA increased by 50 to $70 \%$ in the afternoon (Fig. 4A). TMA concentrations showed no significant change. The turnover time of DMA was shortest (average $8.2 \mathrm{~h}$ ) of the $3 \mathrm{MA}$ (Fig. 4B). Without replication it is impossible to know whether the TMA turnover time at 08:00 h is representative. Uptake rates for MMA and TMA showed only slight changes during the day, while DMA uptake rates were higher, particularly in the afternoon (Fig. 4C).

Uptake rates for all 3 MA were higher at higher temperature (Table 1). These trends are in agreement with the increase in uptake rates of MA measured in Flax Pond during the warmer periods (see also Fig. 3B).

\section{Kinetic parameters}

Maximum uptake rates $\left(V_{\max }\right)$ and transport constants $\left(K_{t}\right)$ for MMA, DMA, and TMA measured in March 1991 and July 1992 are shown in Table 2. Among the $3 \mathrm{MA}, V_{\max }$ of TMA was 10 to 30 times faster than MMA and DMA, $K_{t}$ of DMA was 8 times higher than MMA and about half that of TMA. In the spring, $K_{t}$ of TMA was 100 times lower than the summer sample.
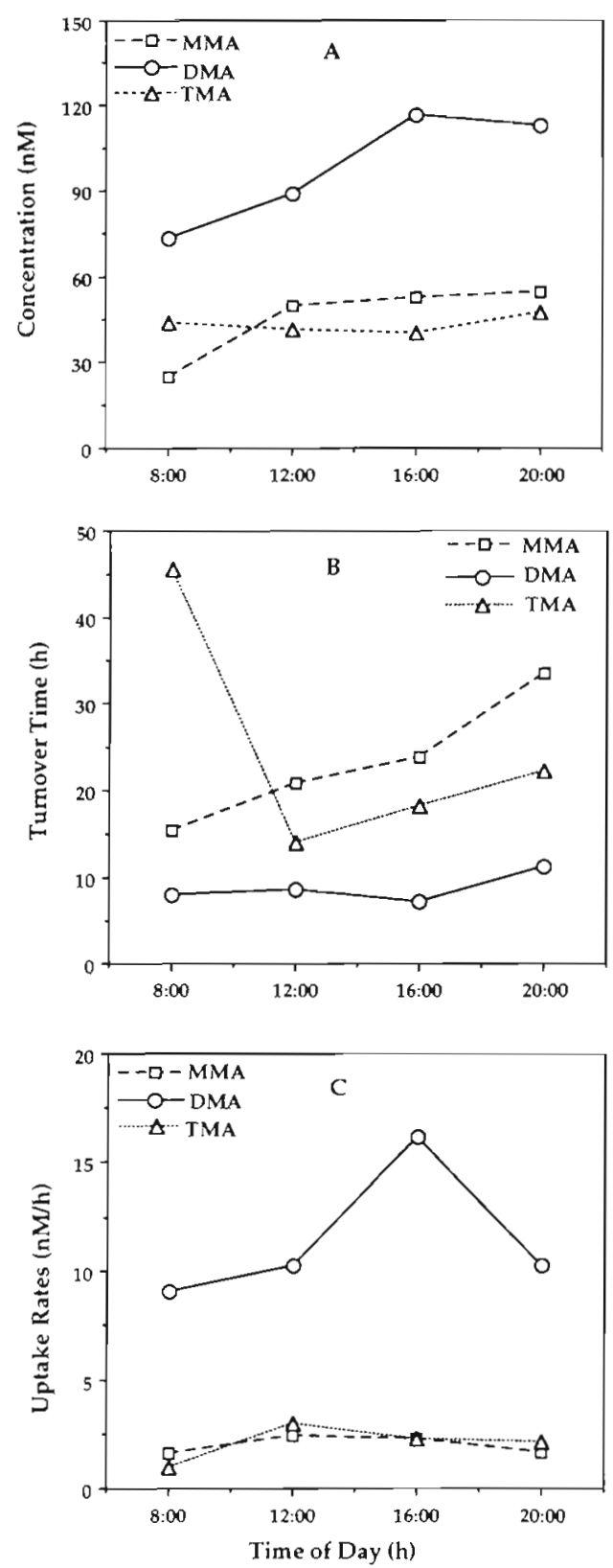

Fig. 4. Daily variations in (A) concentrations, (B) turnover times, and $(\mathrm{C})$ heterotrophic uptake rates of $\mathrm{MMA}, \mathrm{DMA}$, and TMA on 2 August 1990 in Flax Pond seawater 
Table 1 Uptake rates $\left(\mathrm{nM} \mathrm{h}^{-1}\right)$ of methylamines as a function of temperature

\begin{tabular}{|lccc|}
\hline & $7^{\circ} \mathrm{C}$ & $24^{\circ} \mathrm{C}$ & $Q_{10}$ \\
\hline MMA & 0.05 & 0.32 & 3.8 \\
DMA & 0.09 & 0.23 & 1.4 \\
TMA & 0.03 & 0.12 & 2.4 \\
\hline
\end{tabular}

Table 2. Kinetic parameters for methylamine uptake

\begin{tabular}{|lcc|}
\hline & $\begin{array}{c}K_{t} \\
(\mu \mathrm{M})\end{array}$ & $\begin{array}{c}V_{\max } \\
\left(\mu \mathrm{M} \mathrm{h}^{-1}\right)\end{array}$ \\
\hline MMA (July) & 3.3 & 0.14 \\
DMA (July & 26.7 & 0.05 \\
TMA (July) & 58.8 & 1.7 \\
TMA (March) & 0.57 & 0.01 \\
\hline
\end{tabular}

Table 3. Uptake rates $\left(\mathrm{nM} \mathrm{h}^{-1}\right)$ of methylamines in competition experiments

\begin{tabular}{|c|c|c|c|c|}
\hline & Seawater & $\begin{array}{c}\text { Seawater + } \\
1 \mu \mathrm{M} \mathrm{NH}_{4}^{+} \\
\text {(B) }\end{array}$ & $\begin{array}{l}\text { Seawater + } \\
0.6 \mu \mathrm{M} M \mathrm{~A} \\
\text { (C) }\end{array}$ & $\begin{array}{c}\text { Seawater + } \\
1 \mu \mathrm{MHH}_{4}^{+}{ }^{+} \\
0.6 \mu \mathrm{MMA} \\
\text { (D) }\end{array}$ \\
\hline MMA & 1.1 & 2.2 & 3.0 & 2.1 \\
\hline DMA & 13.6 & 13.7 & 8.9 & 7.2 \\
\hline TMA & 0.5 & 1.0 & 11.7 & 9.9 \\
\hline
\end{tabular}

\section{Competition experiments}

Heterotrophic uptake rates of MA were not much affected by addition of ammonium to seawater (Table 3). However, in the MA-enriched treatments (C \& D, Table 3 ), uptake rates increased greatly for TMA, decreased somewhat for DMA, and remained about the same for MMA compared to the natural and ammonium-enriched treatments (A \& B, Table 3).

\section{Tank experiment}

Concentrations of MA in the tank were lower after $1 \mathrm{~d}$ of isolation than concentrations measured in the Pond (Fig. 5). At the end of $24 \mathrm{~h}$, turnover times of MMA and DMA were 6 to 10 times shorter in the tank than in the ambient seawater (100 to 150 h) (Fig. 6). Microbial uptake rates of MMA and DMA were also systematically faster (up to 4 times faster) in the tank than in the Pond (Fig. 7).
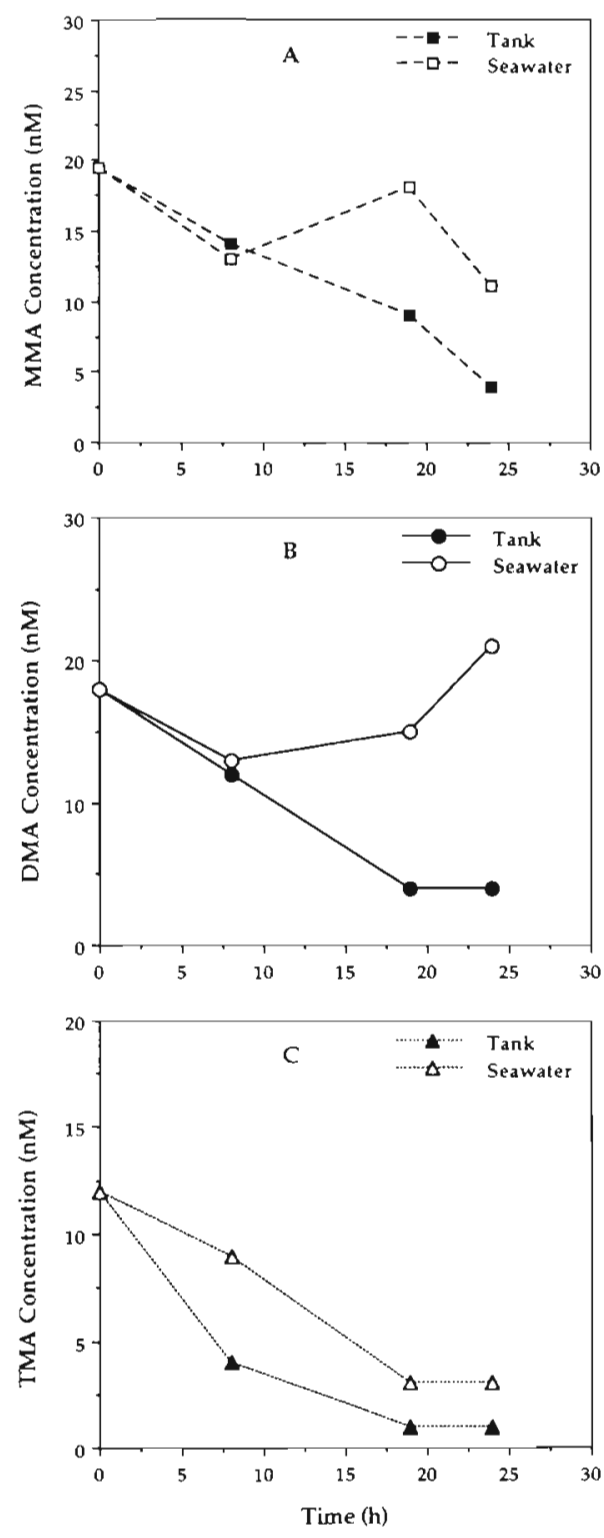

Fig. 5. Concentrations of (A) MMA, (B) DMA, and (C) TMA in an isolated tank and ambient Flax Pond seawater in May 1992. Initial incubation time was $14: 00 \mathrm{~h}$

\section{DISCUSSION}

\section{Seasonal variations}

Strong seasonal variations of concentrations and uptake rates of $\mathrm{MA}$ in seawater were observed (Fig. 3A, C). Both concentrations and heterotrophic uptake rates of $\mathrm{MA}$ were much higher in the warmer months from May to September than during the winter. Concentrations of DMA, MMA, and TMA were higher in May and September than in winter in sediment pore waters and the sediment solid phase of Flax 

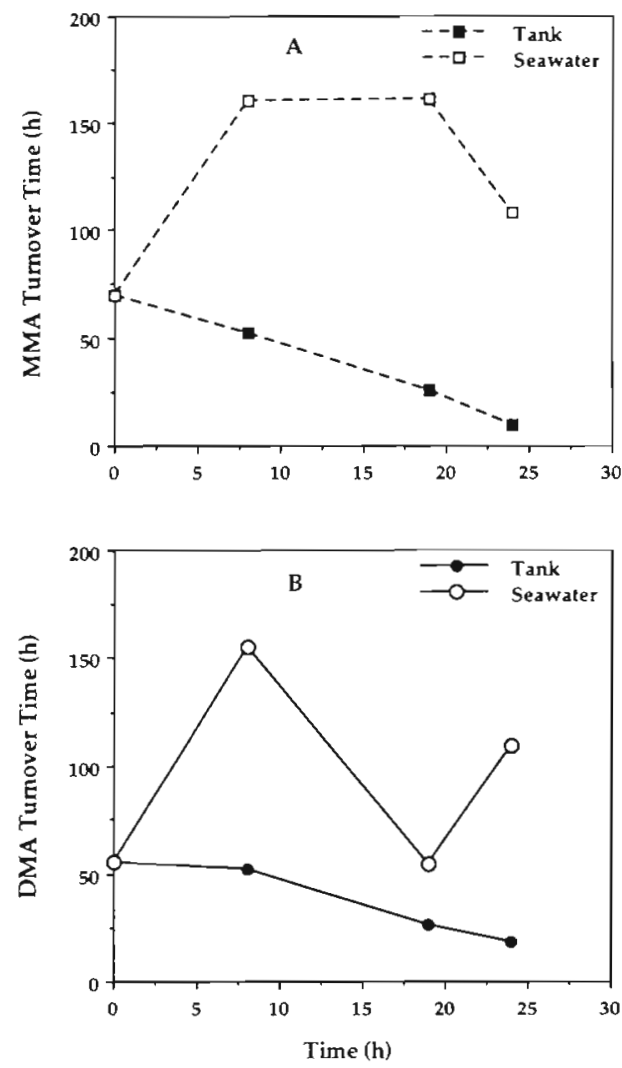

Fig. 6. Turnover times of (A) MMA and (B) DMA in an isolated tank and ambient Flax Pond seawater in May 1992. Initial incubation time was 14:00 h

Pond (Wang \& Lee 1990, unpubl.). Similar results have been found in water and sediment pore water of a Danish estuary where higher concentrations of TMA were measured in spring and early summer than in winter (Sørensen \& Glob 1987). These trends suggest that a major source of MA to both the sediment and overlying water is biological production either directly from phytoplankton or marsh grasses, or indirectly from secondary producers. High primary productivity and biomass occur in spring and fall in Long Island Sound as in most temperate seas. In addition, in the fall, decomposition of Spartina marsh grasses is a major input of organic matter to marsh sediments.

Several methylamine precursors such as choline ( $\mathrm{CHO}$ ), glycine betaine (GBT) and trimethylamine oxide (TMAO) are present in many algae and animals found in marshes and coastal waters (Yancey et al. 1982, King 1988). Some macroalgae contain high concentrations of TMA and TMAO (up to $1 \mathrm{mmol} \mathrm{g}^{-1}$ dry wt; Fujiwara-Arasaki \& Mino 1972). Marsh grasses (e.g. Spartina alterniflora and S. patens) have large amounts of GBT ( 30 to $270 \mu \mathrm{mol} \mathrm{g}^{-1}$ dry wt; Cavalieri \& Huang 1981, Cavalieri 1983, King 1988). Various
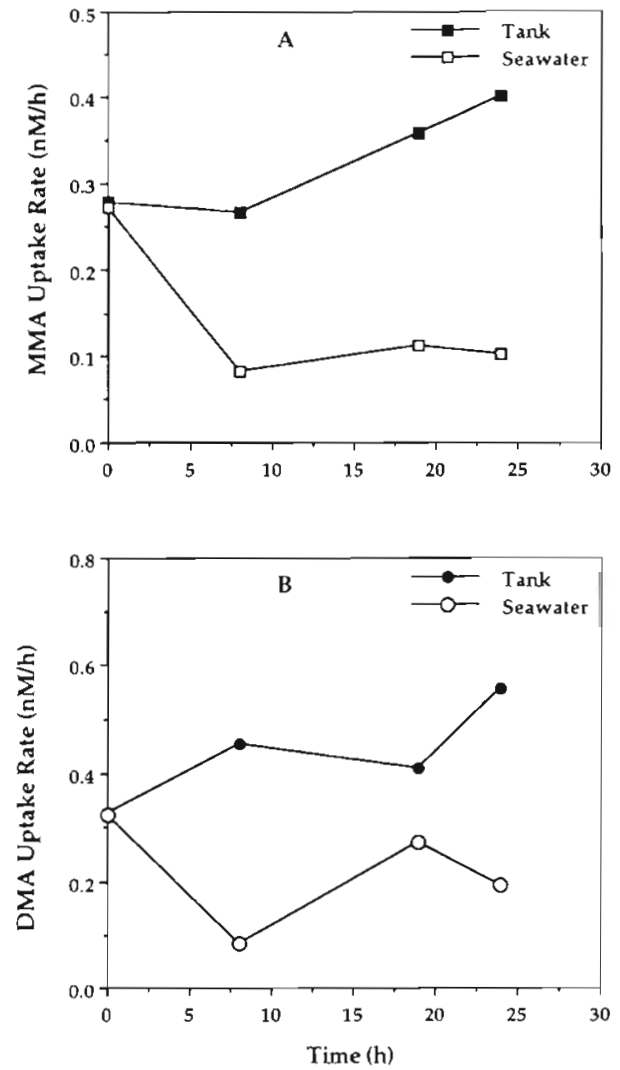

Fig. 7. Heterotrophic uptake rates of (A) MMA and (B) DMA in an isolated tank and ambient Flax Pond seawater in May 1992. Initial incubation time was $14: 00 \mathrm{~h}$

invertebrates and vertebrates are rich in TMAO (up to $140 \mu \mathrm{mol} \mathrm{g}^{-1}$ fresh wt) and GBT (Hebard et al. 1982, King 1988). Bacteria and cyanobacteria contain TMA, TMAO, and GBT (Le Rudielier \& Bouillard 1983, Reed et al. 1984). These quaternary amines are easily degraded to TMA and other products (including acetate and ethanol) by bacteria (Walther et al. 1981, Englard et al. 1983, King 1984). TMA and MMA have been observed frequently in algae (Rolle et al. 1971, Smith 1975) and also have been identified as excretion products in culture medium, suggesting that MMA and TMA also are released by the algae (Rolle et al. 1971, Herrmann \& Juttner 1977).

High concentrations of TMA have been found in slurries of salt marsh sediments amended with fresh Spartina foliosa leaves (Oremland et al. 1982). Sørensen \& Glob (1987) observed high TMA pore water concentrations that were associated with the maximum in faunal density in spring and early summer, and also when degrading macroalgae (Ulva lactuca) accumulated in the stagnant water in the estuary. These studies suggest that direct excretion of TMA by osmoregulating animals or degradation of plants might 
be important sources of TMA (and possible the other $\mathrm{MA}$ ) in the sediments.

Uptake rates of all 3 methylamines were higher in summer reflecting the higher temperatures then. The uptake rates increased later in the summer than the MA concentrations suggesting that the microbial community responsible for consuming the MA may have taken some time to acclimate to higher MA production. Under oxic conditions, TMA can be oxidized to DMA, MMA, formaldehyde, carbon dioxide and ammonium by heterotrophic microorganisms (Colby et al. 1979, Bicknell \& Owens 1980. Naumann et al. 1984).

The higher concentrations of DMA relative to MMA and TMA in seawater are rather puzzling. DMA is the most prevalent MA in human and rat urine (Asatoor \& Simenhoff 1965, Zeisel et al. 1985). The source is considered to be the breakdown of TMA, but production is not thought to occur entirely through a quaternary amine metabolic pathway and is not entirely dependent on gut bacteria. Other sources of DMA are unknown but Asatoor \& Simenhoff (1965) suggested that methylation of MMA by methionine might also be an important source. In our study, microbial decomposition rates of DMA were as fast as or faster than those of the other MA, so the production rate must have been faster as well to sustain the higher concentrations observed.

\section{Daily variation}

In an attempt to examine in further detail the relationship between consumption and production of MA, the uptake rates and the concentrations of methylamines were measured throughout the day. Concentrations of MA and DMA increased slightly in the afternoon while turnover times for MMA, and possibly TMA, also increased slightly (Fig. 4A, B). This resulted in a roughly constant uptake rate (Fig. 4C) and suggests that there was net production of DMA during the daytime. DMA production could occur due to the breakdown of quaternary amines and TMA in algae or as products of bacterial metabolism of algal products.

The daily differences observed were measured over different parts of the tidal cycle and at slightly different water temperatures $\left(22\right.$ to $\left.26^{\circ} \mathrm{C}\right)$. Tidal effects on uptake rates and concentrations of MA are not known. Input of MA may be higher at low tide than at high tide because of the influence of the sediments which are a likely source of these compounds to the water column (Wang \& Lee 1990, but see later discussion). Generally, the depths of the sampling areas were about $60 \mathrm{~cm}$ above the sediment. Further investigation is needed to understand diel cycles of production and consumption of $\mathrm{MA}$ in marine environments.

\section{Competition experiments}

Several previous studies found that uptake rates of MMA by different microorganisms were significantly inhibited by added ammonium. For example, uptake rates of MMA by nitrifying bacteria (Glover 1982), $\mathrm{N}_{2}$ fixing bacteria (Mazzucco \& Benson 1984), blue green algae (Kleiner \& Fitzke 1981), and phytoplankton (Wheeler 1980, Koike et al. 1983, Wright \& Syrett 1983) were all inhibited by ammonium addition. However, in the present study, rates of heterotrophic bacterial uptake of MMA (as well as DMA and TMA) were not depressed by ammonium added to the medium (compare treatment $B$ with the control $A$, or $C$ with $D$; Table 3). Uptake rates of the MA were generally similar in ammonium-enriched treatments and in the nonenriched culture. Bacterial cell number and activities also showed no significant differences between treatments A and B (Jørgensen et al. 1993). The difference in observed sensitivity to ammonium between our studies and previous ones may be due to differences in MA metabolic capabilities. In our experiments, ${ }^{14} \mathrm{C}$ MA were respired to $\mathrm{CO}_{2}$; the MA taken up did not simply accumulate in the cells. Previous studies were conducted using organisms that transported but did not metabolize MMA. Most previous studies also were conducted at concentrations of MMA higher than $K_{t}$ and using pure cultures of microorganisms rather than at tracer level concentrations of amines and with natural communities as in the present study.

Although TMA apears to have larger direct sources in the marsh (Wang \& Lee unpubl.), DMA and MMA have higher concentrations than TMA in the competition experiments and in the control which may partly relate to the bacterial production of these $2 \mathrm{MA}$. During the competition experiments, concentrations of DMA initially increased by 40 to $60 \%$ and MMA increased by about $15 \%$ in the MA-enrichment treatments (Yang 1991). TMA can be microbially oxidized to DMA and then to MMA and $\mathrm{NH}_{4}$ and $\mathrm{CO}_{2}$ as described in previous laboratory studies (Budd 1969, Colby et al. 1979, Naumann et al. 1984). Meiberg \& Harder (1978) observed that DMA and a small amount of MMA were transiently produced and subsequently consumed by bacteria when the organisms were grown on TMA as the sole source of carbon and energy.

\section{Kinetic parameters}

Kinetic parameters for microbial uptake of the methylamines have not been previously reported for natural seawater. However, our value of $K_{t}$ of MMA was $3.3 \mu \mathrm{M}$ in Flax Pond seawater, similar to the value 
of 2 to $7 \mu \mathrm{M}$ for $\mathrm{N}_{2}$-fixing bacteria (Boussiba et al. 1984, Mazzucco \& Benson 1984) and values observed in phytoplankton of 0.2 to $1.2 \mu \mathrm{M}$ (Koike et al. 1983) and 5.7 and $39 \mu \mathrm{M}$ (Wheeler 1980). $K_{l}$ for MMA is much lower than for DMA and TMA, suggesting that uptake of MMA at low substrate concentrations is more effective as for the other $2 \mathrm{MA}$. $V_{\max }$ for DMA was much lower than for MMA $(3 \times)$ and TMA $(34 \times)$. Rates of DMA uptake measured in the summer (10 to $15 \mathrm{nM}$ $\mathrm{h}^{-1}$ ) often approached $V_{\max }\left(50 \mathrm{nM} \mathrm{h} \mathrm{h}^{-1}\right)$ while uptake rates of MMA and TMA were 100 to 1000 times lower than $V_{\max }$. This suggests that the natural heterotrophic population involved in uptake cannot increase its uptake rate as concentration increases unless the organisms present have additional uptake systems with higher $V_{\max }$ values and thus exhibit multi-phasic kinetics (Azam \& Hodson 1981). $V_{\max }$ for TMA was the highest of the $3 \mathrm{MA}$ in July suggesting the capability for an immediate response to increased inputs of TMA.

The difference in $V_{\max }$ for the 3 amines may explain the difference in their uptake rates in the competition experiments (although the competition experiments were conducted in September). The uptake rate of TMA was more stimulated by the addition of MA than was the uptake of MMA or DMA (Table 3). Uptake rates of TMA were about 20 times higher in MAenriched samples than the control. This may partly explain why the concentration of TMA is always the lowest among the $3 \mathrm{MA}$ in seawater.

\section{Tank experiments}

MA concentrations generally decreased with time both inside and outside the tank: after a day the concentrations were about 3 to $20 \mathrm{nM}$ lower inside the tank (excluding the highest DMA point). There are several possible explanations for why the concentration of MA in the tank decreased more rapidly than in water outside the tank. Either production of amines was reduced inside the tank due to removal of MA sources, or microbial decomposition was higher inside the tank. Microbial uptake rates within the tank were 6 to $9 \mathrm{nM} \mathrm{d}^{-1}$ higher than in the surrounding seawater (Fig. 7). Thus the difference in microbial uptake rates is roughly large enough to account for the difference in loss of MA observed between the tank and ambient seawater $(\sim 15 \mathrm{nM}$ in $24 \mathrm{~h})$.

Turnover times of both MMA and DMA in the tank decreased continually over the day to between 10 and $40 \%$ of their original values (Fig. 6) suggesting the development of a community of microorganisms within the tank that were acclimating to MA uptake. Turnover times and uptake rates outside the tank were much more variable and showed no consistent pattern.
The water temperature inside the tank averaged about $2{ }^{\circ} \mathrm{C}$ warmer than the surrounding water. With $Q_{10}$ values around 1.5 to 3.8 we would expect roughly a 40 to $80 \%$ increase in uptake rate due to temperature. Thus, the combination of acclimating microbial community and elevated temperature most likely explain the differences in uptake rates between the tank and surrounding seawater.

However, the loss of MA to levels in the tank below our detection limit ( 2 to $4 \mathrm{nM}$ ) also could suggest that the tank may have excluded a source of amines that exists in the surrounding waters. We first considered that the sediment might be a source of amines to the seawater since there was no sediment in the tank. Sediments are known to serve as a source of other organic nitrogen compounds, e.g. amino acids (Jørgensen et al. 1981, Jørgensen 1982, Christensen et al. 1983). Wang \& Lee (1990) measured seasonal profiles of MA in sediments at a Flax Pond site near where the tank experiment was conducted. We can estimate a maximum flux from the sediments using this data and a simple diffusion model. Seasonal sediment profiles of MA show that concentrations of MA never decrease towards the sediment water interface by more than $100 \mathrm{nM}$ for MMA and $1000 \mathrm{nM}$ for DMA over the top $8 \mathrm{~cm}$. Assuming a diffusion constant similar to acetate of $1.3 \times 10^{-5}$ $\mathrm{cm}^{2} \mathrm{~s}^{-1}$ (Michelson et al. 1989), the flux of MMA out of

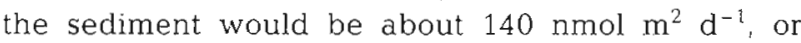
$45 \mathrm{nmol} \mathrm{d}^{-1}$ over the $0.32 \mathrm{~m}^{2}$ of tank bottom surface area. Since the tank volume is $167 \mathrm{l}$, this flux would result in a concentration increase of about $0.3 \mathrm{nM}$ MMA d $d^{-1}$ or 3 nM DMA d $d^{-1}$, or only 6 to $20 \%$ of the 5 (MMA) and 15 (DMA) nM difference observed between the tank and outside seawater. Thus diffusion from the sediments does not appear to be the major source of amines to the water column.

The phytoplankton and zooplankton communities that are known sources of amines were the same inside and outside the tank at the beginning of the incubation experiment. We expect that these populations would not change very much in and outside the tank during $1 \mathrm{~d}$ of enclosure. Wang \& Lee (unpubl.) investigated various sources of amines in Flax Pond and concluded that the Spartina grasses prevalent throughout the marsh were a major source of amines, especially during senescence in the fall. The tank excludes the marsh grasses as a source as amines from the beginning of the experiment. However, further investigation is necessary to determine whether these grasses are a major source of MA to the water column.

Acknowledgements. We thank E. Lamoureux, M. Y. Sun, and $X$. C. Wang for help with sampling. This work was supported by grants from the Office of Naval Research and National Science Foundation. 


\section{LITERATURE CITED}

Asatoor, A. M., Simenhoff, M. L. (1965). The origin of urinary dimethylamine. Biochim. Biophys. Acta 111. 384-392

Azam, F., Hodson, R. E. (1981). Multiphasic kinetics for Dglucose uptake by assemblages of natural marine bacteria. Mar. Ecol. Prog. Ser. 6: 213-222

Balch, W. M. (1985). Lack of an effect of light on methylamine uptake by phytoplankton. Limnol. Oceanogr. 30: 665-674

Balch, W. M. (1986). Exploring the mechanism of ammonium uptake in phytoplankton with an ammonium analogue, methylamine. Mar. Biol. 92: 163-171

Bicknell, B., Owens, J. D. (1980). Utilization of methyl amines as nitrogen sources by non-methylotrophs. J. gen. Microbiol. 117: 89-96

Billen, G., Joiris, C., Wijnant, J., Gillain, G. (1980). Concentration and microbiological utilization of small organic molecules in the Scheldt Estuary, the Belgian coastal zone of the North Sea and the English Channel. Estuar. coast. mar Sci. 11: 279-294

Budd, J. A. (1969). Catabolism of trimethylamine by a marine bacterium, Pseudomonas NCMB 1154. Mar Biol. 4: $257-266$

Budd, J. A., Spencer, C. P. (1968). The utilization of alkylated amines by marine bacteria. Mar. Biol. 2: 92-101

Boussiba, S., Dilling, W., Gibson, J. (1984). Methylammonium transport in Anacystis nidulans R-2. J. Bacteriol. 160: $204-210$

Cavalieri, A. J (1983). Proline and glycinebetaine accumulation by Spartina alterniflora Loisel in response to $\mathrm{NaCl}$ and nitrogen in the marsh. Oecologia 57: 20-24

Cavalieri, A. J., Huang, A. H. C. (1981). Accumulation of proline and glycinebetaine in Spartina alternuflora Loisel in response to $\mathrm{NaCl}$ and nitrogen in the marsh. Oecologia 49: $224-228$

Christensen, J. P., Rowe, G. T., Clifford, C. H. (1983). The possible importance of primary amino nitrogen in nitrogen regeneration by coastal marine sediments in Buzzards Bay, Massachusetts. Int. Rev. ges. Hydrobiol. 68: 501-512

Colby, J., Dalton, H., Whittenbury, R. (1979). Biological and biochemical aspects of microbial growth on $C_{1}$ compounds. Ann. Rev. Microbiol. 33: 481-517

D'Elia, C. F., Cook, C. B. (1988). Methylamine uptake by zooxanthellae-invertebrate symbioses: insights into host ammonium environment and nutrition. Limnol. Oceanogr. 33: 1153-1165

Englard, S., Blanchard, J. S., Miura-Fraboni, J. (1983). Production of trimethylamine from structurally related trimethylammonium compounds by resting cell suspensions of $\gamma$-butyrobetaine- and D, L-carnitine-grown Acinetobacter calcoaceticus and Pseudomonas putida. Arch. Microbiol 135: 305-310

Fujiwana-Arasaki, T., Mino, N. (1972). The distribution of trimethylamine and trimethylamine oxide in marine algae. In: Nisizawa, K. (ed-in-chief) Proc. 7 th int. Seaweed Symp. (Sapporo, Japan). University Press, Tokyo, p. 506-510

Glover, H. G. (1982). Methylamine, an inhibitor of ammonium oxidation and chemoautotrophic growth in the marine nitrifying bacterium Nitrosococcus. Arch. Microbiol. 132; $37-40$

Gottschalk, G. (1986). Bacterial metabolism. Springer-Verlag, New York

Gunnersen, J., Yellowlees, D., Miller, D. J. (1988). The ammonium/methylammonium uptake system of Symbiodinium microadriaticum. Mar. Biol. 97: 593-596

Hebard, C. E., Flick, G. J., Martin, R. E. (1982). Occurrence and significance of trimethylamine oxide and its deriva- tives in fish and shellfish. In: Martin, R. E., Flick, G. J., Hebard, C. E., Ward, D. R. (eds.) Chemistry and buochemistry of marine food products. AVI Publ., Westport, CT, p. $149-304$

Hermann, V., Juttner, F. (1977). Excretion products of algae. Identification of biogenic amines by gas-liquid chromatography and mass spectrometry of therr trifluoroacetamides. Analyt. Biochem. 78: 365-373

Jorgensen, N. O. G. (1982). Heterotrophic assimulation and occurrence of dissolved amino acids in a shallow estuary. Mar. Ecol. Prog. Ser. 8: 145-159

Jorgensen, N. O. G., Blackburn, T. H., Henriksen, K., Bay, D. (1981). The importance of Posidonia oceanica and Cymodocea nodosa as contributors of free amino acids in water and sediment of seagrass beds. P.S.Z.N. I: Mar. Ecol. 2: $97-112$

Jørgensen, N. O. G., Kroer, N., Coffin, R. B., Yang, X.-H., Lee, C. (1993). Dissolved free amino acids, combined amino acids, and DNA as sources of carbon and nitrogen to marine bacteria. Mar. Ecol. Prog. Ser. 98: 135-148

Kerby, N. W., Rowell, P., Stewart, W. D. P. (1986). The uptake and metabolism of methylamine by nitrogen-fixing cyanobacteria. Arch. Microbiol. 143: 353-358

King, G.M. (1984). Metabolism of trimethylamine, choline and glycine betaine by sulfate-reducing and methanogenic bacteria in marine sediments. Appl. environ. Microbiol. 48: 719-725

King, G. M. (1988). Distribution and metabolism of quaternary amines in marine sediments. In: Blackburn, T. H., Sorensen, J (eds.) Nitrogen cycling in coastal marine environments. John Wiley \& Sons, New York, p. 143-173

King, G. M., Klug, M. J., Lovley, D. R. (1983). Metabolism of acetate, methanol and methylated amines in intertidal sediments of Lowes Cove, Maine. Appl. environ. Microbiol. 45 : $1848-1853$

Kleiner, D., Fitzke. E. (1981). Some properties of a new electrogenic transport system: the ammonium (methylammonium) carrier from Clostridium pasteurianum. Biochem. Biophys. Acta 641: 138-147

Koike, I., Redalje, D. G., Ammerman, J W., Holm-Hansen, O. (1983). High affinity uptake of an ammonium analogue by two marine microflagellates from the oligotrophic Pacific. Mar. Biol. 74: 161-168

Lee, C. (1992). Controls on carbon preservation: the use of stratified water bodies to compare intrinsic rates of decomposition in oxic and anoxic systems. Geochim. Cosmochim. Acta 56: 3323-3335

Lee, C., Olson, B. L. (1984). Dissolved, exchangeable and bound aliphatic amines in marine sediments: initial results. Org. Geochem. 6: 259-263

Le Rudielier, D., Bouillard, L. (1983). Glycine betaine, an osmotic effector in Klebsiella pneumoniae and other members of the Enterobacteriaceae. Appl. environ. Microbiol. 46: $152-157$

MacFarlane, J. J., Smith, F. A. (1982). Uptake of methylamine by Ulva rigida: transport of cations and diffusion of free base. J. exp. Bot. 33: 195-207

Mazzucco, C. E., Benson, D. R. (1984). $\left[{ }^{14} \mathrm{C}\right]$ methylammonium transport by Frankia sp. strain CpI1. J. Bacteriol. 160: $636-641$

Meiberg, J. B. M., Harder, W. (1978). Aerobic and anaerobic metabolism of trimethylamine, dimethylamine and trimethylamine in Hyphomicrobium X. J. gen. Microbiol. 106: $265-276$

Michelson, A. R., Jacobson, M. E., Scranton, M. I., Mackin, J. E. (1989). Modeling the distribution of acetate in anoxic estuarine sediments. Limnol. Oceanogr. 747-757 
Mopper, K., Zika, R. G. (1987). Free amino acids in marine rains: Evidence for oxidation and potential role in nitrogen cycling. Nature 325: 246-249

Naumann, E., Fahlbusch, K, Gottschalk, G. (1984). Presence of a trimethylamine: HS-coenzyme $M$ methyltransferase in Methanosarcina barkeri. Arch. Microbiol. 138: 79-83

Oremland, R. S., Marsh, L. M., Polcin, S. (1982). Methane production and simultaneous sulfate reduction in anoxic, salt marsh sediments. Nature 296: 143-145

Reed, R. H., Chudek, J. A., Foster, R., Stewart, W. D. P. (1984). Osmotic adjustment in cyanobacteria from hypersaline environments. Arch. Microbiol. 138: 333-337

Rolle, I., Payer, R., Soeder, C. J (1971). Über die Amine einzelliger Grünalgen. Arch. Mikrobiol. 77: 185-195

Smith, T. A. (1971). The occurrence, metabolism and function of amines in plants. Biol. Rev. 46: 201-241

Smith, T. A. (1975). Recent advances in the biochemistry of plant amines. Phytochemistry 14: 865-890

Sørensen, J., Glob, E. (1987). Influence of benthic fauna on trimethylamine concentrations in coastal marine sediments. Mar. Ecol. Prog. Ser. 39: 15-21

Van Neste, A. Duce, R.A., Lee, C. (1987). Methylamines in the marine atmosphere. Geophys. Res. Lett. 14: 711-714

Walther, R., Fiebig, K., Fahlbusch, D., Caspari, D., Hippe, H., Gottschalk, G. (1981). Growth of methanogens on methylamines. In: Dalton, H. (ed.) Microbial growth on C-1 compounds, Growth of methanogens on methylamines. Heyden \& Son, London, p. $146-151$

Wang, X. C., Lee, C. (1990). The distribution and adsorption behavior of aliphatic amines in marine and lacustrine sediments. Geochim. Cosmochim. Acta 54: 2743-2758

This article was submitted to the editor
Wheeler, P. A. (1978). Uptake of methylamine (an ammonium analogue) by the marine macrophyte Macrocystis pyrifera (phaeophyte). J. Phycol. 14: 12-17

Wheeler, P. A. (1980). Use of methylammonium as an ammonium analogue in nitrogen transport and assimilation studies with Cyclotella cryptica. J. Phycol. 16:328-334

Wheeler, P. A., Hellebust, J. A. (1981) Uptake and concentration of alkylamines by a marine diatom. Plant Physiol. 67: $367-372$

Wright, R., Hobbie, J. E. (1966). Use of glucose and acetate by bacteria and algae in aquatic ecosystems. Ecology 47 : $447-468$

Wright, S. A., Syrett, P. J. (1983). The uptake of methylammonium and dimethylammonium by the diatom, Phaeodactylum tricornutum. New Phytol. 95: 189-202

Woodwell, G. M., Pecan, E. V. (1973). Flax Pond: an estuarine marsh. Brookhaven National Laboratory, BNL 50397, Upton, NY

Yang, X.-H. (1991). Concentrations and biological uptake of three methylamines in marine, estuarine and lacustrine waters. M.S. thesis, State University of New York at Stony Brook

Yang, X.-H., Lee, C., Scranton, M. I. (1993). Determination of nanomolar concentrations of individual dissolved low molecular weight amines and organic acids in seawater. Analyt. Chem. 65: 572-576

Yancey, P. H., Clark, M. E., Hand, S. C., Bowlus, R. D., Somero, G. N. (1982). Living with water stress: evolution of osmolyte systems. Science 217: 1214-1222

Zeisel, S. H., Dacosta, K. A., Fox, J. G. (1985). Endogenous formation of dimethylamine. Biochem. J. 232: 403-408

Manuscript first received: September 9, 1993

Revised version accepted: March 2, 1994 